\title{
The Evaluation of Protein Oxidation in The Rats Which Induced Diabetes by Streptozotocin
}

\section{Streptozotosin Diyabeti Oluşturulan Ratlarda Protein Oksidasyonunun Değerlendirilmesi}

\author{
(D)Meltem Demir', ㅈader Köse², Cevat Yazıcı ${ }^{2}$ \\ 'Blim University, Faculty of Health Sciences, Antalya, Turkey \\ ${ }^{2}$ Erciyes University, Faculty of Medicine, Department of Biochemistry, Kayseri, Turke \\ Copyright@Author(s) - Available online at www.dergipark.org.tr/tr/pub/medr \\ Content of this journal is licensed under a Creative Commons Attribution-NonCommercial 4.0 International License.
}

\begin{abstract}
Aim: Diabetes mellitus (DM) is a chronic disorder and characterized by the development of long-term complications. Methylglyoxal (MGO), a precursor of advanced glycation endproducts (AGE), is detoxified in the organism by Glyoxalase through Glyoxalese I (GLO I) and GLO II.This study was aimed to investigate AGE formation in a diabetic rat model induced by streptozotocin (STZ) and the possible role of melatonin MEL which is a powerful antioxidant in this mechanism.

Materials and Methods:Four study groups, each containing ten Sprague Dawley rats, were defined as control, MEL, STZ and STZ-MEL. STZ and STZ-MEL groups were given a single $50 \mathrm{mg} / \mathrm{kg}$ dose of STZ to induce diabetes. MEL, $25 \mathrm{mg} / \mathrm{kg}$ was given intraperitoneally to MEL and STZ-MEL groups on a daily basis for 42 days. At the end of study, the levels of MGO, GLO I and GLO II enzymes were also determined in only tissue samples.

Results: Blood and urine glucose levels were found to be high in rats $(p<0.05)$. STZ group had been shown to have higher tissue MGO levels and lower GLO I and GLO II activities $(\mathrm{p}<0.05)$. MEL treatment had suppressed high levels of MGO and increased enzymatic activities in STZ-MEL group.

Conclusion: In this study, we have shown that reducing MGO tissue levels in chronic diabetes to almost normal level and that the GLO system suppressed in diabetic rats are preserved with MEL,GLO I and GLO II activities increased. It has been shown that STZ induced diabetic rats had high MGO levels and the supression of GLO detoxification system indicates that AGE formation in diabetes is inevitable. Therefore, the usage of antioxidants such as MEL may be suggested to prevent diabetic complications.
\end{abstract}

Keywords: Diabetes mellitus, Methylglyoxal, Protein Oxidation

Öz

Amaç: Diabetes mellitus (DM) uzun süreli komplikasyonların gelişmesi ile karakterize kronik bir hastalıktır. İleri glikasyon son ürünleri (AGE) öncüsü olan metilglikoksal (MGO) Glioksalaz 1 (GLO 1) ve GLO 2 ile Glioksalaz tarafından organizmada detoksifıye edilmektedir. Bu çalışmada amaç streptozotosin (STZ) ile indüklenen diyabetik rat modelinde AGE oluşumunu araştırmak ve güçlü bir antioksidan olan melatonin (MEL)'in bu mekanizmadaki güçlü antioksidan rolünü araştırmaktır.

Materyal ve Metot: Her biri on adet Sprague Dawley ratları içeren dört çalışma grubu kontrol, MEL, STZ ve STZ-MEL olarak tanımlandı. STZ ve STZ-MEL gruplarına diyabeti indüklemek için tek doz $50 \mathrm{mg} / \mathrm{kg}$ STZ verildi. $25 \mathrm{mg} / \mathrm{kg}$ MEL, 42 gün boyunca MEL ve STZ-MEL gruplarına günlük intraperitoneal olarak verildi. Çalışmanın sonunda sadece doku örneklerinde MGO, GLO 1 ve GLO 2 enzimlerinin düzeyleri tespit edildi.

Bulgular. Ratlarda kan ve idrar glikoz düzeyleri yüksek bulundu $(\mathrm{p}<0.05)$. STZ grubunun daha yüksek doku MGO düzeylerine ve daha düşük GLO I ve GLO II aktivitelerine sahip olduğu $(\mathrm{p}<0.05)$ gösterilse de MEL tedavisi, yüksek MGO düzeylerini ve STZ-MEL grubunda artmış enzim aktivitelerini baskıladı.

Sonuç: Bu çalışmada, kronik diyabetteki MGO doku düzeylerinin neredeyse normale düştüğünü ve diyabetik sıçanlarda GLO sisteminin baskılanmasının MEL, GLO 1 ve GLO 2 aktiviteleri ile korunduğunu gösterdik. STZ kaynaklı diyabetik sıçanların yüksek MGO seviyelerine sahip olduğu ve GLO detoksifıkasyon sisteminin baskılanmasının diyabet hastalığında AGE oluşumunun kaçınılmaz olduğu gösterilmiştir. Bu nedenle, MEL gibi antioksidanların kullanımı, diyabetik komplikasyonları önlemek için önerilebilir.

Anahtar Kelimeler. Diyabetes mellitus, Metilglioksal, Protein oksidasyonu

Geliş Tarihi / Received: 15.08.2021 Kabul Tarihi / Accepted: 26.08.2021

Sorumlu Yazar /Corresponding Author. Meltem Demir, Department of Physiology, Bilim University, Vocational

School of Health Services, Antalya, Turkey, E-mail: meldemir52@gmail.com 


\section{INTRODUCTION}

Diabetes mellitus (DM) is a set of metabolic diseases characterized by hyperglycemia induced by defects in insulin secretion, insulin action, or both (1). Although hyperglycemia is widely acknowledged as the most important risk factor for the development of diabetes complications, it is still debated which pathogenic mechanisms produce these complications. Many complex mechanisms such as increased carbonyl stress (2), oxidative stress (3) and the formation of advanced glycation end products (AGE) (4) are responsible for the development of diabetes complications. According to the classification made in 1980 by the committee of experts formed by the World Health Organization (WHO) and the Diabetes federation, two main forms of diabetes, namely TYPE 1 (Insulin-dependent IDDM) and Type 2 (Insulinindependent NIDDM) diabetes were defined, and the definitions of "juvenile" and "adult" diabetes were used in the naming of these forms (5).

Studies on experimental animals plays an important role in the understanding of diseases, the direction of treatments, and the discovery of new treatment methods. The animals most commonly used as diabetes models are rats, cats, dogs, cows, rabbits, and mice (6). Alloxan and streptozotocin (STZ) are chemical agents that are preferably used in the formation of experimental diabetes today (7). Despite the fact that their mechanisms differ, it is suggested that both have cytotoxic effects via free oxygen radicals (FOR) (8).

Oxidative stress is defined as the disruption of the balance between oxidant-antioxidant systems in the organism in cases where reactive oxygen species (ROS) is overproduced or antioxidant mechanisms are insufficient (9). Cross-linking reactions that can occur within or between molecules have been stated to have an association with protein oxidation and glycation reactions.

Glycation is the nonenzymatic covalent bonding of reducing sugars, primarily glucose, to amino groups of proteins. It's called "Maillard." In glycoxidation, reactive intermediates (á-oxoaldehydes) such as methylglyoxal (MGO), glyoxal (GO), and 3-de-oxyglucocone (3-DG) are formed as the second step of Maillard reactions (10). MGO is a three-carbon aldehyde with a double carbonyl group that can be derived from carbohydrates, lipids, and even proteins in the organism. The main pathways responsible for MGO degradation in the organism are the glyoxalase detoxification system and alpha-keto aldehyde dehydrogenase pathway found in the cytosol of all cells (11). The glyoxalase system, which uses reduced glutathione (GSH) as a cofactor, has two different enzyme activities: Glyoxalase I (GLO I), Glyoxalase II (GLO II). MGO has been proposed as the most important precursor in the formation of AGE in recent years, and this view is supported by high plasma and/or tissue MGO levels in diabetic patients and experimental diabetes models (12).
In addition to its known effects on endocrine function and circadian rhythm, melatonin (MEL), a pineal gland hormone, has also been shown to have antioxidant activity in vitro and in vivo studies (13). It has been reported that it can protect the organism from the negative effects of diabetes and prevent oxidative damage in diabetic rats although the effect of MEL on AGE formation is still unknown (14).

The aim of this study is to assess the glyoxalase detoxification system as well as the MGO levels that cause AGE formation in an experimental diabetes model, as well as to look into the possible interaction of a strong antioxidant such as melatonin on these mechanisms.

\section{MATERIAL AND METHOD}

Erciyes University School of Medicine's Animal Care and Use Committee has approved all the experimental protocols (Approval number: TT-03-07;03/32).

Study group consisted 40 male Sprague Dawley rats, 4-5 months old, weighing 250-350 g. Experimental study was conducted in Erciyes University Hakan Çetinsaya Experimental Research Application and Research Center.

Induction of diabetes A single dose of freshly prepared STZ $(50 \mathrm{mg} / \mathrm{kg}$, dissolved in $0.1 \mathrm{M}$ cold citrate buffer, $\mathrm{pH}$ 4.5) was administered for the induction of DM in overnight-fasted rats. Rats were tested for the induction of DM after 3 days of STZ administration by evaluating their fasting blood glucose levels via a commercial glucometer (Medisense Optium, Abbott, Switzerland). Only rats with fasting blood glucose levels $>200 \mathrm{mg} / \mathrm{dL}$ were included in the present study.

Experimental design Forty male rats were divided into four groups ( $n=10$ per group) as follows: Control Group:Normal control (negative control without any treatment, CONT); Melatonin Group,:Only $25 \mathrm{mg} /$ $\mathrm{kg}$ Melatonin administration, MEL); Streptozotocin Group,;Diabetic rats, STZ; Streptozotosin+Melatonin Group,;Diabetic rats treated with melatonin at $25 \mathrm{mg} / \mathrm{kg}$ for 6 weeks (STZ + MEL)

Liver homogenates; The liver of the treated rats were rinsed with isotonic saline, and their homogenates were prepared immediately $(10 \%[\mathrm{w} / \mathrm{v}]$ in $0.1 \mathrm{M}$ phosphatebuffered saline, $\mathrm{pH}$ 7.4) using a tissue homogenizer. Their supernatants were prepared by centrifugation and were used to measure MGO,GLO I,GLO II parameters.

MGO levels in liver tissue were determined employing the method developed by Cooper. The principle of the method is based upon measuring the color intensity of phenylhydrazones formed by MGO with dialdehyde structure and 2,4-dinitrophenylhydrazine (DNPH) at $550 \mathrm{~nm}$ (15). The method developed by Mannervick was used for the determination of tissue GLI I activity The methods principle is based upon the fact that S-dlactoylglutathione (SLG) formation by GLO I, which catalyzes the conjugation of GSH and MGO, at $240 \mathrm{~nm}$ as a time dependent increase in OD (16). The method 
developed by Racker was employed for the determination of tissue GLO II activity. The principle of the method is based upon monitoring the decrease in OD at $240 \mathrm{~nm}$ due to the conversion of SLG to lactate by GLO II (17). GLO I and GLO II activities and MGO levels were determined in liver tissues obtained from rats.

Statistical comparisons were conducted utilizing SPSS for Windows 10.0 software package. ANOVA and postANOVA (Scheffe procedure) tests were performed. The level of significance was accepted as $p<0.05$ in all statistical comparisons.

\section{RESULT}

Results showed that there was no significant difference between the control and MEL groups in terms of tissue MGO and GLO I and GLO II activities. In the STZ group, MGO levels were found to be significantly higher, while GLO II activity significantly decreased, and GLO I activity have shown a more significant decrease than only the MEL group. The increase in MGO values in the STZMEL group was also found to be statistically significant. When STZ and STZ-MEL groups were compared, it was observed that MGO levels decreased with the effect of MEL, but could not reach the levels of the control group. On the other hand, it was determined that the GLO II activity in the STZ-MEL group reached levels of the control and MEL groups.

All data of the study groups were presented in Table 1.

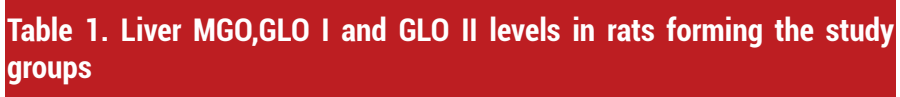

GROUPS MGO (nmol/mg pt) GLO I (U/mg pt) GLO II (U/mg pt)

$\begin{array}{lccc}\text { CONT } & 1.41 \pm 0.027 & 0.084 \pm 0.017 & 0.049 \pm 0.018 \\ \text { MEL } & 1.44 \pm 0.31 & 0.095 \pm 0.02 & 0.051 \pm 0.018 \\ \text { STZ } & 3.34 \pm 0.43 \star^{\mathrm{a}} & 0.061 \pm 0.019^{\mathrm{a}} & 0.024 \pm 0.008 \star^{\mathrm{a}} \\ \text { STZ-MEL } & 2.12 \pm 0.26 \star^{\mathrm{ab}} & 0.074 \pm 0.044 & 0.054 \pm 0.018^{\mathrm{b}}\end{array}$

CONT=Control, MEL=Melatonin, STZ=Streptozotocin, Values are given as mean \pm S.D., for ten rats per group. Values are statistically significant at $p<0.05$; Statistical significance was compared with in the groups as follows: a) diabetic STZ rats groups were compared with normal control rats, b) STZ+MEL

\section{DISCUSSION}

Unclear remains how and under which pathological mechanism hyperglycemia poses the most important risk factor in the development of DM complications. Even if the experimental models used to understand this disease do not meet the real conditions in which human diabetes occurs, they are very advantageous in terms of showing the diabetic state biochemically, hormonally, and morphologically (18).
Considering the mechanisms associated with the pathogenesis of diabetes complications, it is seen that these mechanisms, which are based on different foundations, overlap with each other.

The complexity of the physiopathology of diabetes becomes more apparent when considering the fact that oxidative stress accelerates the formation of AGEs, in addition to the fact that AGE formation causes oxidative stress, and that lipid peroxidation products such as malondialdehyde (MDA), which are formed as a result of oxidative stress, are also an reactive carbonyl compounds (RCC), thus causing carbonyl stress (10).

MGO is a reactive dicarbonyl intermediate and a precursor of AGEs. Significant amount of evidence can be regarded as the increase of MGO levels in diabetic patients (19). MGO can be very cytotoxic making stable adducts. Its concentration levels are found to be significantly higher in the plasma of diabetic patients and diabetic animal tissues. (20) MGO is a physiological substrate of the glyoxalase system, as well as being a physiological a-dicarbonyl compound derived from glycolytic intermediates produced during the Maillard reaction. In this system, which utilizes reduced glutathione as a cofactor, MGO is converted to D-Lactate via SLG intermediates (21). In the experimental models, the significance of MGO in terms of endothelial dysfunction in diabetes was presented an increase in oxidative stress (22). According to Nemet et al. (23), it was shown that whole blood and plasma MGO levels, which were found to be high in both diabetic groups, were statistically significant only in plasma when MGO whole blood and plasma levels of patients with Type I and Type II diabetes were compared. MGO levels were similarly found to be high in kidney, lens, and blood samples from rats with STZ diabetes (24). However, Ohmori et al. (25) reported that MGO levels were low in liver tissues and high in skeletal muscle of rats 72 hours after the alloxan administration. Discrepancies in tissue MGO results in the literature can be attributable to methodological differences as well as experimental diabetic circumstances such as dose and duration.

In this study, liver tissue MGO levels were found to be high in the diabetic rat group. The glyoxalase system, which is common in almost every tissue of the organism and catalyzes the detoxification of MGO, may also affect MGO levels. Any suppression of this detoxification system can be the cause of the increase in MGO levels.

Although there are many studies in the literature investigating the effect of diabetes on GLO I and GLO II activities, the findings obtained from these studies differ.

According to Brouwers et al. in rats having Stz diabetes, GLO-I activity was found to be significantly increased in multiple tissues of all transgenic rats compared to wildtype (WT) littermates (26).

There are studies that reported the GLO I activity to be high in skeletal muscle (27) but low in liver (28) in 
diabetic rats. GLO II activity was similarly discovered to be normal in the tissues of small intestine (29) and high in skeletal muscle (30) but low in kidney (31) and liver (32). Both GLO I and GLO II activities were found to be reduced in the liver tissue of diabetic rats in this study, which is consistent with some of the current literature. These data can be interpreted as partially supporting the increase in MGO levels.

Melatonin is a hormone that is produced by the pineal gland. It plays the role of antioxidant in the oxidantantioxidant imbalance that could be the result of diabetes (33) .The previous studies conducted by Montilla et al. have revealed that melatonin decreased hyperglycemia and hyperlipidemia in rats with STZinduced diabetic (34) Yavuz et. al stated that Melatonin protect the rats' $\beta$-cells from the destructive effects of STZ. The treatment of melatonin $(200 \mu \mathrm{g} / \mathrm{kg} / \mathrm{d}$, ip) for 3 days before the induction of diabetes and then the treatment of melatonin every day for 4 weeks restored the morphology and $\beta$-cell insulin levels, and increased major decrease of glutathione peroxidase activity in pancreatic tissue (35).

MGO levels were lower in the melatonin group than in the STZ+MEL group in our study, although GLO I and Glo II levels were higher.

\section{CONCLUSION}

The fact that the GLO detoxifying mechanism is suppressed, in addition to high MGO levels in the diabetes model produced with STZ, indicates that AGE generation is inevitable in diabetes when all of the findings of this study are evaluated together the literature. In the prevention of these highly complex pathogenic mechanisms; According to the results of the study, it has been found that melatonin has the protective feature against oxidative stress and decreased the severity of STZ-induced diabetes.

Congresses The study has been presented at the '1th National Congress of Dr Safiye Ali' between August 6-7, 2021.

Financial disclosures: Financial disclosures: This research was supported by the Scientific Research Projects Unit of Erciyes Üniversity with the project number TT-03-07;03/32.

Conflict of Interest: The authors declare that they have no competing interest.

Ethical approval: Erciyes University School of Medicine's Animal Care and Use Committee has approved all the experimental protocols (Approval number: TT-0307;03/32).

\section{REFERENCES}

1. Sherwin RS. Diabetes mellitus. In: Goldman L, Bennet J (eds), Cecil Textbook of Medicine (21sted). WB Saunders Company, Philedelphia. 2000,pp.1263-85.
2. Kosmachevskaya OV, Novikova NN, Topunov AF. Carbonyl Stress in Red Blood Cells and Hemoglobin. Antioxidants. 2021; 10:253

3. Feillet-Coudray C, Rock E, Coudray C, et al. Lipid peroxidation and antioxidant status in experimental diabetes. Clin Chim Acta. 1999;284:31-43

4. Friedman EA. Advanced glycosylated end products and hyperglycemia in the pathogenesis of diabetic complications Diabetes Care. 1999;22:65-71.

5. American Diabetes Association. Diagnosis and classification of diabetes mellitus. Diabetes Care 2014;37:81-90

6. Carvalho EN, Carvalho NAS, Ferreiro LM. Experimental model of induction of diabetes mellitus rats. Acta Cir Bros. 2003;18: 60-4.

7. Islas S, Monsalve CR, Pena JE, et al. STZ and alloxan experimental diabetes: comparison of the two models in rats. Acta Histochem Cytochem. 2000;33:201-8

8. Szkudelski T. The mechanism of alloxan and streptozotocin action in $\beta$ cells of the rat pancreas. Physiol Res 2001;50:53646.

9. Sies H. oxidative Stress: oxidants And Antioxidants. Exp Physiol 1997;82:291-5.

10. Schalkwijk C. G. and. Stehouwer C.D.A. Methylglyoxal, A highly reactive dicarbonyl compound, in diabetes, its vascular complications and other age-related diseases. Physiol Rev. 2020;100:407-61.

11. Kalapos MP. Methylglyoxal In Living Organisms. Chemistry, Biochemistry, Toxicology And Biological Implications. Toxicol Lett. 1999;110:145-75.

12. Sousa Silva M, Gomes R. A, Ferreira A. E. N et al. The glyoxalase pathway: the first hundred years... and beyond. Biochem J. 2013;453:1-15.

13. Hardeland R, Reiter RJ, Poeggeler B. et al. The significance of the metabolism of the neurohormone melatonin: Antioxidative protection and formation of bioactive substances. Neurosci Biobehav Rev. 1993;17:347-57.

14. Maritim AC, Moore BH, Sanders RA. et al. Effect of melatonin on oxidative stress in streptozotocin-induced diabetic rats. Int J Toxicol. 1999;18:161-6.

15. Cooper RA. Methylglyoxal Synthase. Methods Enzymol. 1975;41:502-8.

16. Mannervick B,Ridderstrom M:Catalytic and molecular properties glyoxalase I. Biochem Soc Trans. 1993;21:515-7

17. Racker E. The mechanisms of action of glyoxalase. J Biol Chem. 1951;190:685-96.

18. Chunguang C, Christian M.C, Julia S. et al. Human beta cell mass and function in diabetes: Recent advances in knowledge and technologies to understand disease pathogenesis. Mol Metab. 2017;6:943-957.

19. Groener J, Oikonomou, D. Cheko, R. et al. Methylglyoxal and advanced glycation end products in patients with diabetes - what we know so far and the missing links. Exp Clin Endocrinol Diabetes. 2019;127:497-504.

20. Sena CM, Matafome P, Crisostomo J et al. Methylglyoxal promotes oxidative stress and endothelial dysfunction. 
Pharmacol Res. 2012;65:497-506.

21. Yamada $\mathrm{H}$, Miyata $\mathrm{S}$, Igaki $\mathrm{N}$ et al. Increase in 3 deoxyglucosone levels in diabetic rat plasma. Specific in vivo determination of intermediate in advanced Maillard reaction. J Biol Chem. 1994;269:20275-80.

22. Nigro C, Leone, A, Raciti, G. L. et al. Methylglyoxal-Glyoxalase 1 Balance: The Root of Vascular Damage. Int J Mol Sci. 2017; 18:188.

23. Nemet I, Turk Z, Dunjakd L et al. Humoral methylglyoxal level reflects gylicemic fluctuation. Clin Biochem. 2005;38:37983.

24. Phillips SA, Mirrlees D, Thornalley PJ. Modification of the glyoxalase system in streptozotocin-induced diabetic rats. Effect of the aldose reductase inhibitor statil. Biochem Pharmacol. 1993;46:805.

25. Ohmori S, Mori M, Kawase $M$. et al. Determination of methylglyoxal as 2-methylquinoxaline by high-performance liquid chromatography and its application to biological samples. J Chromatogr. 1987;414:149-55.

26. Brouwers, O, Niessen, P. M, Ferreira, I. et al. Overexpression of Glyoxalase-I Reduces Hyperglycemia-induced Levels of Advanced Glycation End Products and Oxidative Stress in Diabetic Rats. J Biol Chem. 2011;286:1374-80.

27. Mey, J. T., \& Haus, J. M. Dicarbonyl Stress and Glyoxalase-1 in Skeletal Muscle: Implications for Insulin Resistance and Type 2 Diabetes. Front Cardiovasc Med. 2018;5:117.
28. Raju J, Gupta D, Rao AR. et al. Effect of antidiabetic compounds on glyoxalase I activity in experimental diabetic rat liver. Indian J Exp Biol. 1999;37:193-5.

29. Cianfruglia, L, Morresi, C, Bacchetti T. et al. Protection of Polyphenols against Glyco-Oxidative Stress: Involvement of Glyoxalase Pathway. Antioxidants. 2020;9:1006.

30. Stadtman ER, Berlett BS. Reactive oxygen-mediated Protein oxidation In Aging And Disease. Chem Res Toxicol. 1997; 10:485-94.

31. Lyons TJ. Glycation, Carbonyl Stress, Eagles, And The Vascular Complications of Diabetes. Semin Vasc Med. 2002;2:175-89.

32. Hollenbach, M. The Role of Glyoxalase-I (Glo-I), Advanced Glycation Endproducts (AGEs), and Their Receptor (RAGE) in Chronic Liver Disease and Hepatocellular Carcinoma (HCC). Int J Mol Sci. 2017;18:2466.

33. Singh M, Jadhav HR. Melatonin: Functions and Ligands. Drug Discov Today. 2014;19:1410-8.

34. Montilla PL, Vargas JF, Tunez IF, et al. Oxidative stress in diabetic rats induced by streptozotocin: protective effects of melatonin. J Pineal Res. 1998;25:94-100.

35. Yavuz O, Cam M, Bukan N. et al. Protective effect of melatonin on beta-cell damage in streptozotocin-induced diabetes in rats. Acta Histochem. 2003;105:261-6. 